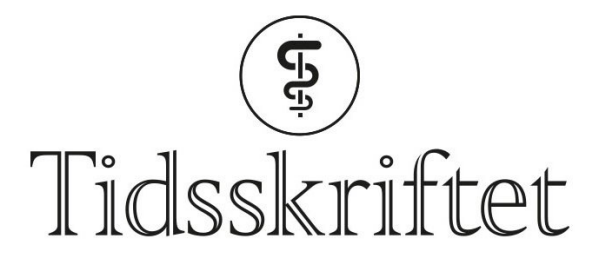

DEN NORSKE LEGEFORENING

\title{
Arrfri tilheling av sår?
}

FRA ANDRE TIDSSKRIFTER

RUTH HALSNE

Tidsskriftet

Omdanning av myofibroblaster til adipocytter kan forhindre arrdanning, men bare med hårfollikler til stede.

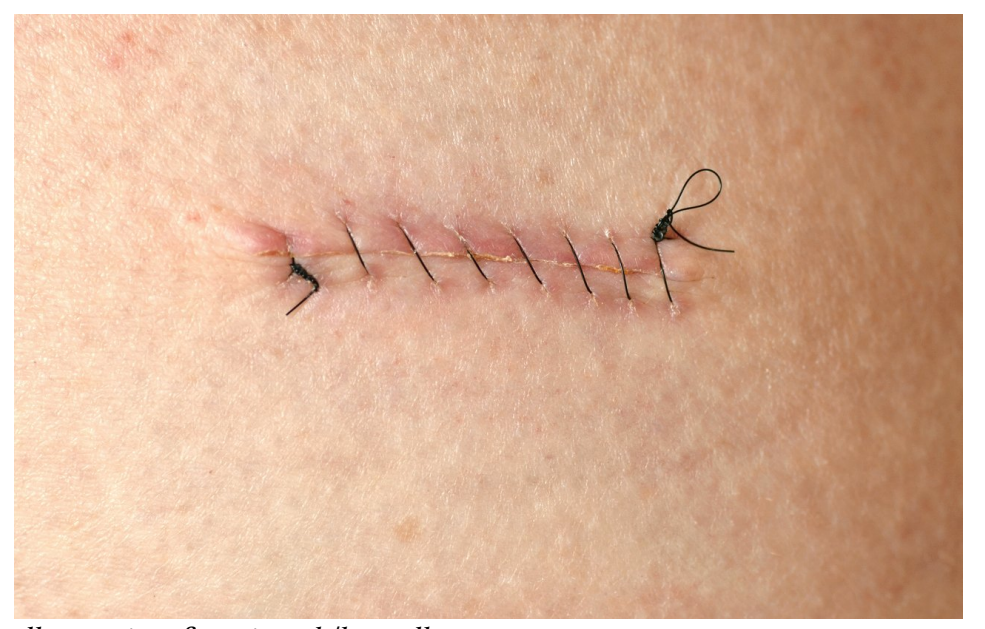

Illustrasjonsfoto: iStock/bgwalker

Arr mangler behåring og fettvev. Arrvev domineres gjerne av myofibroblaster, som deponerer store mengder kollagen, og disse har vært regnet som en cellelinje uten mulighet for å differensiere. Men i en nylig publisert musestudie påviste en forskergruppe i USA adipocytter rundt nydannede hårfollikler ved store overflateskader og at disse adipocyttene var transformerte myofibroblaster, uten bidrag fra andre celletyper (1). Transformering var bare mulig ved tilstedeværelse av hårfollikler og under påvirkning av benmorfologisk protein (bone morphogenetic protein, BMP).

Fra tidligere er det kjent at BMP-signalering kan indusere regenerering av adipocytter in vitro. I denne studien fant man at sårtilheling hos mus med økt ekspresjon av en BMPantagonist ikke ga regenerering av fett selv om de formet normale hårfollikler. For å verifisere dette funnet ble BMP-reseptoren fjernet. Musene hadde da ikke lenger evnen til å transformere myofiborblaster.

- Arrfri tilheling har vært plastikkirurgiens hellige gral, sier Kjersti Ausen, som er plastikkirurg og overlege ved St. Olav hospital i Trondheim. - Man har trodd at stamceller er så differensierte etter fosterlivet at arrfri tilheling ikke lenger er mulig, men studien viser at myofibroblaster kan transformeres til fettceller når arrvevet kommer i kontakt med hårfollikler. Man har lyktes med å «skru på igjen» en differensieringsmulighet som ellers 
bare er mulig i embryonale stamceller og i in vitro-studier transformert keloid arrvev. Dersom man kan identifisere nøyaktig hvilke signalsubstanser som trigger en slik transformasjon, gir dette spennende fremtidsvyer for behandling av arr, sier Ausen.

LITTERATUR:

1. Plikus MV, Guerrero-Juarez CF, Ito M et al. Regeneration of fat cells from myofibroblasts during wound healing. Science 2017; 355: 748 - 52. [PubMed][CrossRef]

Publisert: 24. mai 2018. Tidsskr Nor Legeforen. DOI: 10.4045/tidsskr.18.0275

(C) Tidsskrift for Den norske legeforening 2020. Lastet ned fra tidsskriftet.no 